Paper for Special issue of Race, Ethnicity and Education on Black Feminism and

Postcolonial Paradigms to be published in March 2009

De-colonising practices: Negotiating narratives from racialised and gendered experiences of education

Ann Phoenix

Thomas Coram Research Unit

Institute of Education University of London

27 Woburn Square

London

WC1H OAA

Tel: $+44(0) 2079115395$

a.phoenix@ioe.ac.uk

Word count with references: 8389 


\title{
De-colonising practices: Negotiating narratives from racialised and gendered experiences of education
}

\begin{abstract}
This paper uses feminist work on diaspora and postcolonial theory to examine the ways in which women serial migrants, who as children left the Caribbean to join their parents in the UK, experienced racialised, gendered intersections in the 'contact zone' of school. Drawing on narrative accounts from 50 women serial migrants the paper argues that school was a key site for racialised subjectification, even though, as girls new to the UK, the participants had not yet come to an understanding of racialisation. Their mastery of a new school system occurred in contexts where they reported being subjected to racist discourses from teachers and other children. It was epistemically violent in that it involved learning that they were constructed as inadequate learners and undesirable femininities. As a result, they experienced subjectification and school itself as painful processes. All, however, reported agency in resisting subjection into representations of themselves as innately incapable. Their retrospective accounts indicated that postcolonial theory can illuminate how migrant children negotiate complex, racialised experiences in education and, in doing so, help to de-colonise everyday practices.
\end{abstract}

Keywords: Caribbean women; contact zones; identities; postcolonial feminism; schooling; serial migration 


\section{Introduction}

The proliferation of postcolonial work over the last fifty years has provided a range of critical approaches to theorising the legacy of colonialism. Its meta-analytic and deconstructive stance has facilitated analyses of the ways in which knowledge is not innocent, but frequently serves to perpetuate and justify the hegemony of excolonisers by Othering as inferior those who were previously colonized and their descendants. Postcolonial paradigms are often dated from the publication of Edward Said's (1978) Orientalism, which demonstrated how the creation of the binary opposites Oriental and 'Western' serve to other the 'Oriental' by constructing westerners as rational (in opposition to Orientals' emotionality) and so justifying their rule. However, Franz Fanon's publications in the early 1970s highlighted the ways in which colonisers and the colonised are inextricably linked in the relational process of racialisation (Fanon, 1963, 1967).

Since Fanon's and Said's pioneering work, postcolonial feminists (e.g. Abu-Lughod 2006, Alexander and Mohanty 1997, Brah 1996, Mohanty 1988, Spivak 1988) have taken forward feminist theory by 'writing back to the centre' from globalised perspectives. Their publications have critiqued the omission of minoritised women from much postcolonial and feminist work and deconstructed their exoticisation and homogenisation (Mohanty 1988). Postcolonial feminist work has highlighted the importance of 'particular local contexts', which are frequently complex, involving intersecting relations of social class, racialisation, ethnicisation and sexuality as well as gender (Brah 1996). Such work has rendered visible the power relations through which minoritised women are positioned and how their treatment frequently fits with a normalised absence/pathologised presence couplet (Phoenix 1987).

For many postcolonialist feminists, travel to the 'West' underlined the disjunction between how they understood themselves and how they were constructed in the societies to which they had migrated. Lata Mani $(1989,11)$, for example, explains that 'The disjunctions between how I saw myself and the kind of knowledge about me that I kept bumping into in the West opened up new questions for social and political inquiry'. This paper addresses disjunctions produced for migrants by examining a postcolonial relation that has received little research attention; the adults from the 
Caribbean who migrated to the UK as children as they encountered the educational system. It draws on feminist work on diaspora and postcolonial theory to interrogate the ways in which cultures and relations are reshaped in 'diaspora space' (Brah 1996) through everyday experiences of education. According to Brah, diaspora space is where genealogies are interlinked, whether or not people have known histories of migration. They are sites in which individual and collective memories and practices 'collide, reassemble and reconfigure.' (p. 193). In consequence they are sites of negotiation and contestation over representational and other practices, where experiences cannot simply be read off from knowing, for example, a migrant history.

The paper is divided into three parts. The first briefly discusses issues of subjectification (i.e. the process by which people come to experience themselves as subjects having particular subjectivities). It examines their relevance to postcolonial relations in diaspora space. The second considers the 'history of the present' by examining socio-cultural particularities in the schooling of African Caribbean children. The final (and longest) section analyses women's narrative accounts from a study of adults who were left in the Caribbean by their parents and later joined them in the UK. The paper examines how (post)colonial legacies intersect with racialisation and gender in experiences of education to produce subjectification as racialised and gendered subjects. It illustrates how postcolonial theory can aid understanding that children who are migrants have to negotiate complex everyday practices in their experience of education. These practices, narrated from adult perspectives, simultaneously reproduce and disrupt colonial relations.

The analyses presented below draw on the accounts of 50 adults who were serial migrants from the Caribbean (38 women and 12 men) who took part in an ESRCfunded research programme on 'Transforming Experience', where data are still being collected and so analyses are preliminary, rather than complete ${ }^{1}$. All the women's parents left the Caribbean at a time when their labour was solicited in the UK (and the USA (Bauer and Thompson 2006), where they hoped to be able to make a more prosperous life, with better opportunities for their children. The children left behind

1 The 'Transforming experiences: Re-conceptualising identities and 'non-normative' childhoods' research programme is funded as an Economic and Social research Council Professorial Fellowship awarded to Ann Phoenix (Award number: RES-051-27-0181). Elaine Bauer and Stephanie DavisGill are Research Fellows on the programme. 
knew many others whose parents had also gone abroad. They were, therefore, neither considered 'non-normative' in the countries in which they had been born, nor in their social circles. It focuses on women's accounts since African Caribbean girls tend to attain better in school than their male peers (Gillborn and Mirza 2000) and are not constructed as so 'hard' (Frosh, Phoenix and Pattman 2002). It might be expected then that they would be better received than their male peers and so illuminate the best possible case.

\section{Subjectification to postcolonial relations in diaspora space}

Issues of representations, power relations, recognition and the psychic and social constitution of subjectification, foregrounded by Fanon (1967) and developed by Althusser (1971); Foucault (1980, 1977); and Butler (2004) are central to the everyday practices of 'diaspora space' (Brah 1996). The discussion below considers the ways in which people come to experience themselves as subjects through processes of normalization and representation (i.e. subjectification) These processes interpellate people as subjects into gendered and racialised relations of power that include state technologies.

Current debates on subjectification owe much to Louis Althusser's (1971) ideas about Ideological State Apparatuses and interpellation. They were, however, prefigured by Frantz Fanon's (1967) theorization of the ways in which the colonizer/colonized relationship is normalized in the psyche-i.e. that the social is simultaneously psychic. Fanon argued that racism produces psychological constructs that both prevent the black man (sic) from seeing his own subjection to a universalized white norm and alienates his consciousness of his own identity.

According to Fanon, the social structure is the 'real source' of 'the black man's' conflict and speaking the colonizer's language leads many black men to don a 'white mask' because the collective consciousness of the colonizer becomes part of their psychology. This fits with later theorization of the subject as a product of power, of apparatuses of normalization and of subjection that does not arise only from their agency (Althusser 1971; Foucault 1977; Butler 1997). For example, Judith Butler suggests that 'the subjects regulated by such structures [juridical systems of power] 
are, by virtue of being subjected to them, formed, defined, and reproduced in accordance with the requirements of those structures' (Butler 1990, 2). This does not mean, however, that subjugation is simply internalized. In her research on black women's subjectivities, Amina Mama (1995) takes a postcolonial approach to argue that black women do not simply take on the identities society positions them to occupy (counter to Fanon's notion of donning a mask), but over time, use their collective histories within oppressive social orders to counteract the racism and sexism they experience. They continually develop new consciousness through personal struggles with the contradictions and subjugation they face. Their subjectivities are, therefore, part of a continuous, creative and dynamic process. Fanon ([1961] 1963) argued that representations are central to the process of colonization. For that process to be successful, the colonisers have to impose their image on the subjugated so that the only ways in which they gain recognition from others, and recognize themselves, are within the images constructed by the colonisers. These justify colonialism through the perpetuation of images of the colonized as inferior. Not surprisingly then, much postcolonial work has been concerned with representations, in literature, cultural studies and identity politics and in 'Western' feminist work. For example, in a now classic paper, Mohanty $(1988,2003)$ argues that Western feminist work frequently reproduces colonial relations by treating the category 'women' in ahistorical ways that fail to recognise differences, for example, of social class, ethnicity, geography etc. This decontextualisation makes it common for 'third world women' to be constructed as exotic, passive and homogeneous victims, dependants and passive.

According to Althusser, people are 'interpellated' as subjects when they recognise themselves to have been 'hailed' by ideology. Metaphorically, this process is akin to what happens when someone recognizes that they are being hailed by a policeman. In everyday life, institutions such as families, churches and schools 'hail' people by including them in categories that prescribe and enforce particular ways of thinking about themselves and of acting as subjects. In these processes people self-define in ways they consider independent and autonomous although they are produced through interpellation. Subjectivity is produced through processes of subjectification. Avtar Brah $(1999,7)$ illustrates how interpellation can involve gendered processes of othering: 
One 'white' mother whom I interviewed in 1976 [in Southall] had said to me: "“Where did they come from?", my father used to say, "they were here, and then the shops opened up.",

The 'they' in this locution signifed 'Asians'. 'She means people like me', I had thought to myself, feeling acutely 'othered'... I could not be a disinterested listener, although I listened attentively. My intellect, feelings, and emotions had all been galvanized by my respondent's discourse. I was framed within it, whether I liked it or not. What was it that made her referent 'they' instantly recognizable as 'Asians' to us both?

Clemente and Higgins (2008) studied Mexican students negotiating marginal positions in relation to English language. They suggest that there are two broad analytic 'panoramas' in postcolonial discourses; critical deconstruction and 'critical focus on the historical and socio-cultural dynamics of the postcolonial condition that illuminates the particularities of the systemic and epistemic violence that framed, and continues to frame, the realities of colonialism and how the social actors in those contexts have resisted those forces' (p. 9). Clemente and Higgins (2005) illustrate these particularities from ethnographic studies of students in Mexico who are in the process of learning and teaching English. They found that the students frame their language activities in terms of their own social and cultural contexts and so locate themselves within World English. In doing so, they move 'beyond the hegemonic constraints of Standard English' and resist being defined as the other in relation to it. 'That is, they are being "themselves in this other language"' (p. 30). This 'being themselves' is gendered as well as ethnicised.

The sections below focus on some of the historical and socio-cultural particularities of the migration experience for adults who were serial migrants to the United Kingdom when they were children. It considers the constitutive part played by schooling in the production of agency and identity for a generation of African Caribbean adults who were serial migrants to the UK. In doing so, it is postcolonial in Clemente and Higgins' (2008) terms since it is both critically deconstructive and focuses on historical and socio-cultural dynamics. Feminist postcolonial work indicates that it is possible to deconstruct colonial representations (Mohanty 1988) and that subjectification involves continual processes of struggle (Mama 1995). 
It is important to note that some postcolonial theorists critique notions of agency and identity as well as of citizenship. Chakrabarty (2000), for example, demonstrates that subalterns frequently refuse agency and subjecthood, ascribing apparently agentic actions to the supernatural or gods. They view work as inseparable from religion, so that it makes no sense to ascribe work identities to them. Other postcolonialist theorists, however, treat agency and subjectivity as central to postcolonialism in, for example, its concern with who speaks for whom (Spivak 1988). Kapoor (2002, 655), for example, interrogates the work of postcolonial theorists such as Said, Bhaba and Spivak to argue that 'agency and subjection....are intimately related: the type and degree of agency is tied to the type and degree of power'. Resistance is produced by subjection and is evident at the local level. It is in this local sense that notions of agency and identity are employed psychosocially (i.e. simultaneously psychologically and socially) below to refer to the ways in which the women discussed act in relation to their subjection and the inextricable linking of subjection, agency and identity.

\section{Socio-cultural particularities in the schooling of African Caribbean children}

Children of West Indian parents, [then] the largest of all the immigrant groups, have been a source of bafflement, embarrassment and despair in the education system. They have often presented problems which the average teacher is not equipped to understand, let alone overcome (Rose and Deakin 1969, 281).

In the 1960s and 1970s, 'West Indian' children were considered to have language difficulties and behaviour problems and to come from families with inadequate childrearing, overly harsh control and punishment and deficient family structures (often being lone parent). 'West Indian' parents were said to have unrealistic expectations for their children's education. However, constructions of 'West Indian' children were often based on results from inappropriate IQ tests, which led to disproportionate numbers being classified educationally subnormal (Coard 1977).

Because West Indian children's language pattern was construed as a mark of intellectual disability, some were summarily placed into ESN schools (educationally subnormal schools), for those with IQs of 80 or below... The disproportionate number of West Indian children found in classes for the retarded has become a source of concern for the British school system and one of befuddlement for teachers (Thomas 1980, 83). 
The inappropriateness of the judgements based on inadequate IQ testing is attested to both by research (such as that reported by Thomas above) and by reports of experience:

Geoff Palmer arrived in London from Jamaica in 1955... a month before his 15 th birthday... His mother took him to the local school, where he was given a routine IQ test. "I'd just travelled 5,000 miles from Jamaica. The test asked me 'How does Big Ben indicate the time?"' he chuckles. "The questions meant nothing to me. Absolutely nothing." He was told he was "educationally subnormal" (ESN) ... Palmer's saving grace was his cricketing prowess. He was spotted by the local grammar school head and awarded a place. Today he is Professor Geoff Palmer, OBE, of Heriot Watt University, one of only a handful of black chemistry professors in Britain. (Curtis 2005)

National statistics on educational attainment by ethnicity were not recorded in the UK until the introduction of the Pupil Level Annual Schools Census (PLASC) in 2002. However, the evidence available from the 1960s onwards consistently indicated that there were ethnicised differences in attainment (e.g. Little, Mabey and Whitaker 1968, Rampton 1981, Swann 1985, Yule, et al. 1975).

Although 'West Indian' children were subjected to racism because they were West Indian (Gillborn, 1988), gender differences were as prevalent amongst West Indian children as amongst the white majority ethnic group (Willis 1977). Boys were more likely to be placed in schools for the educationally subnormal and some girls 'qualified their criticisms' of how they were treated in school in order to get qualifications they considered critical (Bryan, Dadzie and Scafe 1986, Coard 1977, Fuller 1980).

Unlike white majority ethnic children, being middle class does not protect black young people from poor educational performance (Gillborn and Mirza, 2000, Rollock 2007). The US psychologist Claude Steele developed a theory that provides a partial explanation for why this might be. He argues that when social identity is attached to a negative stereotype, people will tend to underperform in ways consistent with the stereotype (Steele and Aronson 1995). Steele (1997) suggests that this 'stereotype threat' results from anxiety about confirming negative stereotypes that impairs test 
performance. While Steele provides a psychological explanation for the process by which racism produces differential attainment by ethnicity, Gillborn (2008) develops a sociological argument that these differences are so consistent, resistant to change and are subject to shifting goalposts, that they have to be seen as produced by 'concerted practices'. Gillborn's historically-informed analyses indicate how pervasive are negative constructions of, and racist discourses on, black children and how postcolonial relations continue to be relevant in contexts where postcolonial encounters are so ubiquitous, that they are rarely recognised as such.

These psychological and sociological processes operate simultaneously to produce a process of subjectification in which children from the (ex-)colonies are positioned in ways that necessitate their engagement with constructions of themselves as devalued. It would, therefore, be easy for them to be interpellated into constructions of themselves as problematic in much the way that Brah (1999) and Mani (1989) found themselves interpellated into recognition of their Otherness in encounters with a research participant and as a new igrant to the USA respectively. The section below considers how those encounters are remembered by women who migrated to the UK from the Caribbean in childhood and the implications of the postcolonial dynamics they encountered for their subjectification.

\section{Negotiating racialised/gendered subjugation as school subjects}

From a postcolonial perspective, Mary Louise Pratt (1991) refers to the dynamics of multicultural classrooms as one type of 'contact zone', or 'social spaces where cultures meet, clash, and grapple with each other, often in contexts of highly asymmetrical relations of power, such as colonialism, slavery, or their aftermaths as they are lived out in many parts of the world today' (Pratt 1991, 6). The notion of 'contact zones' is relevant to the study of adults who have experienced serial migration in that it foregrounds (post)colonial encounters when there is 'spatial and temporal copresence of subjects previously separated by geographic and historical disjunctures, and whose trajectories now intersect' (Pratt 1992, 7). Pratt's 'contact perspective' both fits with Brah's notion of interlinkage in 'diaspora space' and 'emphasizes how subjects are constituted in and by their relations to each other. It treats the relations among colonizers and colonized, or travelers and "travelees," not 
in terms of separateness or apartheid, but in terms of copresence, interaction, interlocking understandings and practices, often within radically asymmetrical relations of power' (Pratt 1992).

The school experiences of students of Caribbean origin show ways in which copresence and relations are negotiated and resisted in interactions between colonizers and colonized. These demonstrate both asymmetric relations of power (Pratt, 1992) and systemic and epistemic violence (Clemente and Higgins 2008). A radio interview with the black British Member of Parliament Diane Abbott, who was born in the UK in 1953 and started secondary school in 1964 demonstrates these complexities:

Diane Abbott: ...I was always good at... writing essays, and I was famous in my primary school for my essays. And I remember we were given an essay writing assignment, and at the second lesson she read out the marks. She started at the top and went down to the bottom. She started with A+, A, A- and she still hadn't called my name. So I was a bit surprised because I never got less than an A in my primary school. And she read out everyone's names and everyone's grade and not my name. So I went up to her afterwards, and she had a desk, which was on a kind of dais, it was about, sort of, six inches above. And she picked up the essay with her thumb and her finger and she literally looked down on me and she said, 'Where did you copy this essay?' because she could not believe that this chubby, bespectacled black girl with her plaits in front of her could have written that essay. And I was mortified. And what happened, actually, and it's interesting because I think it...I think a lot of children react to low expectations like that. I--in my mind--I didn't go home and complain to my parents, you know, I just for the remainder, really, of that year wrote down, because I was frightened of being humiliated like that again. And it wasn't until my second year when I had an English teacher who really believed in me, that I was able to blossom again...

Kirsty Young: At what point in your schooling, then, did...your teachers think this girl is Oxbridge material?

Diane Abbott: They never thought that, actually. [Laughs] It was a girls' grammar school and there was a very strong culture of achievement, and so on, but I remember it was quite difficult to organise doing Oxford and Cambridge entrance from state schools in those days. And so when I went to my history teacher and told her that I wanted to do the Oxford and Cambridge entrance exam, she looked at me, she paused, and she said, "I don't think you're up to it. And then I said something, which really was absolutely fateful, but I looked at her and I said, without skipping a beat, 'But I do and that's what matters.' Now no-one I knew had stayed at 
school past 16, let alone Oxford and Cambridge, but I just got the idea in my head that I was going to go there, and nobody told me that working class girls, let alone black working class girls, didn't go to Oxford or Cambridge. I didn't know. So I went for it (Abbott 2008).

Abbott's account of her experience highlights how what should be mundane encounters designed to help children invest in their futures can reproduce (post)colonial power relations in ways that serve to (re)position children in devalued ways. As Clemente and Higgins (2008) suggest these historical and socio-cultural dynamics are systemically and epistemically violent. For Diane Abbott, humiliation by her teacher directly led to a deterioration in her work and progress. However, it also showed how postcolonial relations are not absolute, but plural and differentiated in that it was another teacher who helped Abbott to 'blossom again' by 'believing' in her. In a similar way McKellar (1994) reports that her teachers' negative expectations motivated her to succeed. Abbott's account indicates her resistance to being interpellated as 'not up to it' (perhaps because she already had a history of being viewed as educationally successful) and so the struggle over representation identified by Said (1978) and Mohanty (1988). While it is not highlighted in Abbott's account, her positioning as a 'West Indian' child indicates the intersection of gender and racialisation. Not only did she attend a 'girls' grammar school', but the research evidence available suggests that black girls were likely to resist teacher racism in ways that teachers found less challenging than boys' resistance. At the same time teachers considered them inadequate feminine subjects (Fuller, 1980).

Although Diane Abbott was born in London and so is not a migrant, her encounter with teachers in the 'contact zone' of her school in the 1960s both resonates with, and is historically synchronous with those of the serial migrants in the study reported here, who ranged in age from the mid 30s to the early 60s. For example, 'Nanny' (her chosen pseudonym), who arrived in the UK aged fifteen in 1967 joined her new secondary modern school in time to do a biology test with her class. Her teacher assured her that she was not expected to pass since she had not done the work. When she came first in the class and it was obvious that she had not cheated, her teacher demanded to know how she had managed this. For Nanny this interrogation was both surprising and led her to 'coast'. At the other end of the school career, June arrived in 
the UK aged eight years in 1966 and found that, while she was already an accomplished reader, her teacher wanted her to learn the alphabet. As she portrayed it, she (like Diane Abbott) resisted what she viewed as devalued positioning by telling her father, who got her teacher to accept that she could already read.

For many of the sample, accounts of schooling in their new country consistently reiterate three themes: the difficulties of communicating when their Caribbean accents were considered strange and unintelligible; having to deal with racism from their white peers and/or teachers and, related to both these issues; how they were positioned as embodying both cultural and educational backwardness. Angela, exemplifies retrospective recognition of all three elements.

Angela: .... and then of course there was school and that was difficult because I came from a school in Trinidad where I was not highly thought of but I was in the sort of like the top er stream and I came here and I didn't know anything because I didn't understand. Although we spoke English it was different type of English, and I didn't understand the system and there was no support around that and the person I came to live with, my mother she didn't understand, or didn't think that were going to be any issues with, I was quite alone and I was put in the bottom stream as well with the dunces as they said... And it can be very vicious you know name calling, of course you're not speaking English properly so you're backwards and stupid and that sort of thing and so it's very hard to forge friendships and so I think at 14, 15 friendships are very important in your school life. Because that's what it's all about at that age isn't it? And I didn't have that and neither did I have that academic er, confidence either so I didn't know and it was hard. It's making me cry (laugh).

Angela's account portrays the bewilderment and loneliness she felt in a new system where difference, viewed through a racist lens, was equated with deficiency. Her account suggests that she experienced both the pain of being called names and the disjunction of finding herself in the bottom stream with the change of country. The process of subjectification was one where she had to deal with being devalued because of her colour and origin. While Angela laughs when she says 'It's making me cry', the fact that she did cry indicates that this had long-lasting emotional consequences. This is also evident in Josephine's account.

Josephine: $\quad$...Because I, coz of where we came from obviously we had um, with (inaudible) stronger accent than I've got now (laughs). And the children in the school ground used to say to me, "Oh I can't understand you blah, blah, blah, blah", and this is why I make a con-, a, a 
conscious effort not to talk too fast. I always say (inaudible) take my ti-, when I talk to people coz it's sometimes it's (inaudible), "I don't understand you", and they used to take the mickey out of our accent.

Josephine makes a direct link between being teased about her accent and making a conscious effort not to talk too fast'. Equally telling, this part of her account is, at times, inaudible with broken off and re-started words, apparently demonstrating the denting of confidence she identifies as caused by the teasing. While teasing about ways of speaking was frequently reported to have been painful in itself, Caribbean language forms were often treated by teachers and other children as signifying innate incapacity, with the result that children were 'summarily treated as educationally deficient' (Thomas 1980). Language and ways of talking were repeatedly reported by the women in the serial migration study to be a painful site of negotiation and contestation over representations of African Caribbean children. Their reports suggest that the ways in which the children were treated were epistemically violent in reproducing colonial power relations of superiority and inferiority and that, as Fanon (1967) suggests, the necessity of speaking the language of the coloniser forced the children to see themselves through the coloniser's representations.

Processes of subjectification went beyond language, however, so that the children knew that both their language and the countries from which they came were considered metonymic with inferiority.

Hally: I mean I remember when they took me to sign me up for school and stuff like that. And of course they think just because you come from the Caribbean you don't know nothing and put you in the lowest class and stuff like that, but you, you know more than what the other kids do, but they just assume that you know, you're so backwards (laughs) you know. But you know, because I was able to read and do all the work that the other kids- even faster, but after a while you just think, "Oh well, if they're so slow in doing it you might as well just be as slow". Um (.)

\section{/.../}

\section{Q: And in schools?}

Hally: In schools? (.) The experience in school (.) there was a lot of racism I experienced, I must say. Um, but I, I don't think it's, it's, it's, it's 
not something that has made you bitter. The experience I would say it's (.) it moulds you in a way you just, you just get on with it and just say, "Oh well, they are just people, they don't understand" or whatever.

Hally tells a story common to many of the adults' accounts - that they were educationally in advance of their UK peers when they arrived in Britain. Her account gives some insight into processes of subjectification for newly migrant Caribbean children at the time. First, it is clear that she quickly came to recognise her colour and Caribbean origins as markers of difference. In addition, she recognised that that difference positioned her as less able than her peers. That this had far-reaching consequences is indicated by her account of capitulating to what she came to understand as the norm for her peers, in a similar way to Diane Abbott's decision to 'write down'. However, Hally demonstrates the unevenness of processes of subjectification and the importance of theorising agency. She says that 'the experience...it moulds you in a way', but her account indicates that, while she was affected by the racism she experienced in school, she is meta-analytic about it to the extent that, at least partly, she dismisses those who treated her in this way as 'just people', who 'don't understand' and, retrospectively, is able to name racism (as is Lizzie, below).

In the long extract below, Lizzie indicates that her experience of 'diaspora space' in the new 'contact zone' of her first school in the UK, adversely affected her future (Leccardi, 2008). (Leccardi 2005, 2008)

Question: Okay you were just saying that it was a real challenging experience over the years, can you say what you mean by that?

Lizzie: Well I think erm, the first challenging experience I had really, after the four weeks I was registered in to school. And I think that was the most daunting ${ }^{2}$ painful experience that I can ever think of, and I think each time when I reflect back to it I think to myself you know, I just, I think, after a couple of months in school I really hated my parents for bringing me. Cos there I was with my nan in Jamaica, I was loved and there I was at school. I can always remember the children used to follow you and try to lift, pick your dress up to see if you've got a tail. That's the bitter experience of school and I just use to hate school, and then my parents use to force me to school. Cos you had to go to school, they had to go to work you know and I can always remember my mum would sort of get ready in the morning. Cos she was going off to work and then she would drop us to someone to drop us off to school. And those were, thinking back now I

2 Underlining indicates emphasis. 
just thought how ever, did we, did I survive those first couple of years at school? Cos I was the only black child there. But I mean, now that I think of it, I reflect back and I think but after all you were very important because you were the first black child to go to this school... Cos I was quite a bright child when I was growing up in the West Indies and unfortunately I felt that I was, held back, when I came to this country because of the racism and the, misunderstanding of our culture. I don't feel at that time the education system understand people coming in from other countries and the level of education you're bringing with you. So therefore and I remember, and I still think of it now, we, as West Indian we write a certain way. We tend to, I don't know if your parents does it or whatever but we tend to write in flash, I mean we do our, I mean if you see my signature you see the flash. Where we sort of curl the gs and, do you see what I mean?

R Yes.

Lizzie: And we tend to write that way. And I was sort of more or less bullied by the teacher to let go of that style of writing. So in a way I think I went back into myself you know where I was quite bright I then became quite withdrawn. And (.) I don't think my parents understand it as well because they were trying, they wanted the best for us you know. And they had to struggle as well, because they were struggling themselves with racism. So they had to be dealing with it in work and then they would come home and you'd be telling them. And I mean at the time I didn't see it as racism, cos at that time what did you know about racism? You just use to say, they don't like me because I'm black and you know so. Erm, I felt I was pushed back because of that.

Lizzie's account contains some similar elements to Diane Abbott's in that she speaks of how being 'bullied by the teacher' to change her style of writing made her go 'back into myself'. In this sense she was 'foreclosed from possibility' (Butler 2004, 31) in that her 'unlived possibilities' were curtailed, with 'melancholic' consequences (Butler 1995) she considered 'daunting', 'painful' and 'bitter'.

Much that has been quoted so far could equally be reported in black men's retrospective accounts. However, Lizzie's linking of the bitterness of her experience in the new 'contact zone' of the school with children following her to 'try to lift, pick your dress up to see if you've got a tail', is implicitly gendered. Equally, many of the women in the study highlighted how school was the first place where they experienced derogatory comments about their hair. While some men also discussed their unhappiness with having fellow pupils rub their hair whenever they chose, girls' 
hair was reported to be particularly derogated. The painful impact of this is reported in other studies. McKellar (1994), for example, describes being called 'streets' by other children, because of the partings between her plaits. Similarly, the black women in Amina Mama's (1995) study of black women's postcolonial subjectivities frequently dicussed hair (together with food and language) as a site of painful recognition of how the intersection of gender and racialisation constructed them as devalued, unacceptable and undesirable femininities. Mama suggests that black identities are produced in resistance to positioning in colonialist-integrationist discourses that require black people to be like white people that led many black women to feel ashamed of their hair, food and language.

Lizzie's narrative constitutes an example of how prevailing discourses create 'truths' about students as learners that impact on how they see and experience themselves. From her study of a British and an Australian school that are coeducational and multiethnic, Youdell (2006, 55 ) suggests that 'subjectivities are not the stable, interior possessions of a self-knowing subject, but are instead artefacts of discourses that produce these subjects as though they were pre-existing'. The women in the study reported above had to negotiate, in the contact zone of the school, pre-existing discourses of 'West Indian' girls as undesirable and inadequate pupils who fail to meet normative expectations of embodied femininity, Their experiences exemplify the systemic and epistemic violence they faced (Clemente and Higgins 2008) as they began to negotiate the intersections of racialisation and gender in the production of new identities.

\section{In conclusion}

This chapter has employed postcolonial analyses to examine the complex everyday practices that Caribbean women serial migrants remember experiencing in their first encounters with the British education. The context in which the women in the serial migration study arrived in the UK was one where overt racism was common, black people were constructed as outsiders to the nation and 'West Indian' children were constructed as problematic for UK schools. The women' accounts indicate that school was one of the sites where that they were subjugated as racialised subjects in ways which meant that they were not able to 'accomplish' themselves as appropriate 
learners (Davies and Saltmarsh 2007, Youdell 2006). They were, in Butler's terms, 'foreclosed from possibility' (Butler 2004, 31) and, therefore, denied access to full personhood (Riddle, 2007). Their as yet unlived possibilities were curtailed, with 'melancholic' consequences (Butler 1995). Analysis of the women' accounts suggests that this occurred in three ways: they experienced the expectations and standards in the UK as lower than they had been in the Caribbean; they were positioned as embodying lack of ability because of how they spoke and looked and where they came from. Many of the women identified racism as something to which they, as black girls, had been subjected. Postcolonial theory illuminates the ways in which the intersections of racialisation and gender produce constructions of black girls as both inadequate learners and devalued femininities (c.f. Mama, 1995; Mohanty, 2003).

School appears to have been a key site for racialised (and national) subjectification, even though, as girls, they had not yet come to an understanding of racialisation. Their mastery of a new school system was interlinked with subjugation to oppressive power relations and epistemic violence (Clemente \& Higgins, 2008). As a result, they experienced subjectification and school itself as painful processes. This parallels Davies and Saltmarsh's (2007) suggestion that learning literacy is interlinked with gender subjugation. Their experiences in the 'diasporic space' of the classroom as 'contact zone' demonstrate the ways in which they came to recognise western representations that constructed them as inferior (c.f. Brah, 1996; Pratt, 1991). While they were subjected to negative representations that reproduce colonial relations, they used their agency to disrupt those remembered relational experiences in parallel ways to those reported by the black women in Mama's (1995) study of postcolonial subjectivities. All reported agency in resisting subjection into representations of themselves as innately incapable and could be said to be in the process of decolonising their practices. 


\section{References}

Abbott, Diane, interview by Kirsty Young. Desert Island Discs, Radio 4 (18 May 2008).

Abu-Lughod, Lila. "The Muslim woman: The power of images and the danger of pity." E-Zine, 2006: http://www.eurozine.com/articles/2006-09-01-abulughod-en.html. Alexander, M. Jacqui, and Chandra Talpade Mohanty. Feminist Genealogies, Colonial Legacies, Democratic Futures. New York: Routledge, 1997.

Althusser, Louis. "Ideology and Ideological State Apparatuses: Notes towards an Investigation.” In Lenin and Philosophy, by Translated Ben Brewster, 127-186. New York: Monthly Review Press, 1971.

Anzaldua, Gloria. Borderlands/La Frontera: The New Mestiza. 1987.

Bauer, Elaine, and Paul Thompson. Jamaican Hands Across the Atlantic. Jamaica: Ian Randle, 2006.

Brah, Avtar. Cartographies of Diaspora. London: Routledge, 1996.

Brah, Avtar. "The Scent of Memory: Strangers, Our own, and Others." Feminist Review, 1999: 4-26.

Bryan, Beverly, Stella Dadzie, and Suzanne Scafe. The Heart of the Race: Black Women's Lives in Britain. London: Virago, 1986.

Butler, Judith. Gender Trouble: Feminism and the Subversion of Identity. New York: Routledge, 1990.

Butler, Judith. "Subjection, Resistance, Resignification: Between Freud and Foucault ." In The Identity in Question, by John Rajchman, 229-249. London: Routledge, 1995.

-. The Psychic Life of Power: Theories of Subjection (Stanford University Press, 1997). . Stanford : Stanford University Press , 1997.

—. Undoing Gender. New York: Routledge, 2004.

Chakrabarty, Dipesh. Dipesh Chakrabarty, Provincializing Europe . Princeton:

Princeton University Press, 2000.

Clemente, Angeles, and Michael Higgins. Performing English with a postcolonial accent: Ethnographic narratives from Mexico. London: The Tufnell Press, 2008. Clemente, Ángeles, and Michael Higgins. "Whose English is it anyway? Culture, language and identity: Ethnographic portraits from Oaxaca, Mexico." Working Papers on Culture, Education and Human Development, Volume 1, Number 3 (October), 2005: http://www.uam.es/otros/ptcedh/2005v1.

Coard, Bernard. How the West Indian Child is Made Educationally Subnormal in the British School System: The Scandal of the Black Child in Schools in Britain. London: New Beacon Books, 1977.

Collins, Patricia Hill. Black Feminist Thought: Knowledge, Consciousness and the

Politics of Empowerment. 1990.

Conley, Dalton. Honky. USA: Vintage Books, 2001.

Curtis, Polly. “Opportunity locked.” The Guardian Online. 1 February 2005. http://www.guardian.co.uk/education/2005/feb/01/raceineducation.race (accessed August 25, 2008).

Davies, Bronwyn. "Death to critique and dissent? The policies and practices of new managerialism and of 'evidence-based practice'." Gender and Education, 15, , 2003: 89-101.

Davies, Bronwyn, and Sue Saltmarsh. "Gender Economies: Literacy and the Gendered Production of Neo-Liberal Subjectivities." Gender and Education, 19(1), 2007: 1-20. 
Davis, Darren, and Brian Silver. "Stereotype threat and race of interviewer effects in a survey on political knowledge." American Journal of Political Science, 47, 2003: 3345.

Davis, Darren, and Brian Silver. "Stereotype threat and race of interviewer effects in a survey on political knowledge." American Journal of Political Science, 47, 2003: 3345.

Fanon, Frantz. Black Skin, White Masks. New York: Grove, 1967a.

—. Black Skin, White Masks. Translation of Peau noire, masques blancs. Paris, 1952.

New York: Grove, 1967.

—. The Wretched of the Earth. Harmonsdsworth: Penguin, 1967b.

-. The Wretched of the Earth, translated Constance Farrington from 1961 book: Les damnes de la terre. New York: Grove Weidenfeld, 1963.

Foucault, Miche. "The Subject and the Power." In Michel Foucault: Beyond

Structuralism and Hermeneutics, by Hubert Dreyfus and Paul Rabinow, 208-26.

Brighton: Harvester, 1982.

Foucault, Michel. Discipline and Punish: the Birth of the Prison. London: Allen Lane, 1977.

-. Power/Knowledge: Selected Interviews and Other Writings 1972-1977 (ed. C.

Gordon). Brighton: Harvester, 1980.

Foucault, Michel. "Security, Territory, and Population." In Michel Foucault, Ethics:

Subjectivity and Truth, by Paul Rabinow, 67-71. New York: The New Press, 1997.

Frosh, Stephen, Ann Phoenix, and Rob Pattman. Young Masculinities: Understanding

Boys in Contemporary Society. London: Palgrave MacMillan, 2002.

Fuller, Mary. "Black girls in a London comprehensive school." In Schooling for

Women's Work, by Rosemary Deem, 52-65. London: Routledge \& Kegan Paul, 1980.

Gillborn, David. "Ethnicity and Educational Opportunity: Case Studies of West Indian

Male-White Teacher Relationships." British Journal of Sociology of Education, 9(4), 1988: 371-385 .

-. Racism and Education: Coincidence or Conspiracy. London: Routledge, 2008.

-. Racism and Education: Coincidence or Conspiracy? London: Routledge, 2008.

Gillborn, David, and Heidi Safia Mirza. Educational Inequality: Mapping Race,

Class and Gender - A Synthesis of Research Evidence. . London: Office for Standards in Education (OFSTED)., 2000.

Gilroy, Paul. After Empire: Multiculture or Postcolonial Melancholia . London:

Routledge, 2004.

Gunaratnam, Y, and G. Lewis. "Racialising emotional labour and emotionalising racialised labour: anger, fear and shame in social welfare." JOURNAL OF SOCIAL WORK PRACTICE, VOL. 15, NO. 2, 2001: 131-148.

Gunaratnam, Yasmin. Researching 'Race' and Ethnicity Methods, Knowledge and Power. London: Sage, 2003.

Kapoor, Ilan. "Capitalism, culture, agency: dependency versus postcolonial theory." Third World Quarterly, 23(4), 2002: 647-664.

Leccardi, Carmen. "Facing uncertainty: Temporality and biographies in the new century ." Young, 13, 2005: 123-146.

Leccardi, Carmen. "New biographies in the 'risk society'? About future and planning." Twenty-First Century Society. 3(2), 2008: 119-129.

Little, Alan, Christine Mabey, and Graham Whitaker. "The education of immigrant pupils in Inner London primary schools." Race and Class, 1968: 439-452.

Mama, Amina. Beyond the Masks: Race, Gender and Subjectivity. London:

Routledge, 1995. 
Mani, Lata. "Multiple mediations: Feminist scholarship in the age of multiple mediations." Incriptions, 5, 1989: 1-23.

McKellar, Barbara. "Only the fittest of the fittest will survive: Black women and education." In The Education Feminism Reader: Developments in a Field of Study, by Lynda Stone and Gail Masuchika Boldt, 229-241. New York: Routledge, 1994. Mohanty, Chandra Talpade. Feminism Without Borders: Decolonizing Theory, Practicing Solidarity , . London: Duke University Press, 2003.

Mohanty, Chandra Talpade. "Under Western Eyes: Feminist Scholarship and Colonial Discourses." Feminist Review, 1988: 61-88.

Mohanty, Chandra Talpade, Ann Russo, and Lourdes (eds) Torres. Third World Women and the Politics of Feminism. Indianapolis: Indiana University Press, 1991. Parreñas, Rhacel. Children of global migration : transnational families and gendered woes. Stanford: Stanford University press, 2005.

Phoenix, A. "Theories of gender and black families." In Gender Under Scrutiny, by Gaby Weiner and Arnot Madeleine. London: Hutchinson, 1987.

Plewis, I. "Assessing and Understanding the Educational Progress of Children from Different Ethnic Groups ." Journal of the Royal Statistical Society. Series A (Statistics in Society), Vol. 151, No. 2 (1988), pp. 316-326, 1988: 316-326.

Plewis, Ian. "Ethnic group differences in educational attainments and progress revisited." Joint Meeting of the Royal Statistical Society Social Statistics and General Applications Sections: 'Recent Advances in Multilevel Modelling Methodology and Applications'. London, 2007.

Pratt, Mary Louise. "Arts of the contact zone.” Profession, 91, 1991: 33-40.

-. Imperial Eyes: Travel Writing and Transculturation. New York: Routledge, 1992.

Rampton, Anthony. West Indian Children in Our Schools: Interim report of the

Committee of Inquiry into the education of children from ethnic minority groups .

London: Her Majesty's Stationery Office, 1981.

Rollock, Nicola. "Black pupils still pay an ethnic penalty - even if they're rich." The

Guardian Online. 4 July 2007.

http://www.guardian.co.uk/commentisfree/2007/jul/04/comment.education (accessed August 25, 2008).

Rose, Eliot Joseph Benn (Jim), and Nicholas and associates Deakin. Colour and

Citizenship: a report on British Race Relations. Oxford: Oxford University

Press/Institute of Race Relations, 1969.

Said, Edward. Orientalism. London: Routledge \& Kegan Paul, 1978.

Spivak, Gyatri Chakravorty. "Can the subaltern speak?" In Marxism and the

Interpretation of Culture, by Cary Nelson and Lawrence Grossberg, 271-313. London:

Macmillan, 1988.

Spivak, Gyatri Chakravorty. "Can the subaltern speak?” In Marxism and

Interpretation of Culture, by C Nelson and Lawrence Grossberg, 271-313. Chicago,

IL: University of Illinois Press, 1988.

Steele, C, and J Aronson. "Stereotype threat and the intellectual test performance of African-Americans." Journal of Personality and Social Psychology, 69(5) , 1995:

797-811.

Steele, C. M. "A threat in the air: How stereotypes shape intellectual identity and performance." American Psychologist, 52, 1997: 613-629.

Steele, Robert S, and Jill G Morawski. "Implicit Cognition and the Social Unconscious." Theory \& Psychology, 12 , 2002: 37-54. 
Swann, Lord. Education for All: Report of the Committee of Enquiry into the Education of Children from Ethnic Minority Groups. London: Her Majesty's Stationery Office, 1985.

Thomas, William Bonds. "School Response to West Indian Youth Immigrating to England, 1960-1970." Phylon, 1980: 72-88 .

Willis, Paul. Learning to Labour . London: Saxon House, 1977.

Youdell, Deborah. Impossible Bodies, Impossible Selves: Exclusions and Student Subjectivities . Netherlands: Springer, 2006.

Yule, William, Michael Berger, Michael Rutter, and Bridget Yule. "Children of West Indian immigrants - ii. Intellectual performance and reading attainment." Journal of Child Psychology and Psychiatry, Vol. 16. , 1975: 1-17.

Ann Phoenix is Professor and Co-Director of the Thomas Coram Research Unit, Institute of Education University of London. 